\title{
Effects of ICT Integration in Management of Private Secondary Schools in Nairobi County, Kenya: Policy Options and Practices
}

\author{
Charles Richard Oyier ${ }^{1}$, Paul Amollo Odundo ${ }^{1, *}$, Ganira Khavugwi Lilian ${ }^{1} \&$ Kahiga Ruth Wangui ${ }^{1}$ \\ ${ }^{1}$ Department of Educational Communication and Technology, University of Nairobi, P O Box 279-00300, Nairobi, \\ Kenya \\ *Correspondence: Department of Educational Communication and Technology, University of Nairobi, PO Box \\ 279-00300, Nairobi, Kenya. E-mail: oyier1212@yahoo.com
}

Received: July 28, 2015

Accepted: August 22, 2015 Online Published: October 28, 2015

doi:10.5430/wje.v5n6p14

URL: http://dx.doi.org/10.5430/wje.v5n6p14

\begin{abstract}
The convergence between telecommunication, broadcasting multimedia and related technologies commonly known as Information and Communication Technologies (ICT), promises a fundamental change in educational management. ICT could be the missing tool in improving efficiency of private secondary schools to cope with rapidly changing world to effectively meet management tasks combined with flexibility in learning and administrative activities essential in enhancing efficiency in educational institutions. Little evidence explains effect of ICT in private secondary schools management across the globe. The study investigated effects of ICT in management in private secondary schools in Nairobi. A survey design was adopted with target population of 140 private schools and information was sourced from 40 principals, who were randomly sampled. The study found that the adoption of ICT is high in private schools irrespective of curriculum offered. The use of ICT with schools having installed current hardware and software required for implementation of ICT strategy in management. Findings revealed that use of ICT is more in schools with higher enrollment and having both day and boarding components. Uses of ICT enabled institutions achieve improvements in financial, administrative and instruction management. In financial management $62.5 \%$ of schools had automated accounts, $71.9 \%$ payroll and $53.1 \%$ budgeting operations. In administrative management $68.75 \%$ automated stores, $56.25 \%$ students' records and $62.50 \%$ staff records. In instructional management $53.10 \%$ automated timetabling, $84.30 \%$ examinations and $76.90 \%$ students' progress reports. The study recommends regular training of administrators and staff on emerging technologies in school management, deliberate budgetary allocation to procure hardware and software to support ICT in management and government policy to implement ICT in management at all tiers of the economy.
\end{abstract}

Keywords: School management; Private secondary schools; ICT in management; Financial management; Administrative management; Instructional management

\section{Introduction}

Advancements in technology have resulted in rapid changes in modern management including public and private schools. The complexity of technological changes has led to far-reaching developments in managerial systems and especially on management tasks at individual and institutional levels (Makhanu and Kamper 2012). The changes have been necessitated by advancement in Information and Communication Technologies (ICT) and witnessed in all sectors including management of educational institutions. In acknowledging this Roberts and Sikes (2011) asserted that as twenty first century's reality, ICT has necessitated a new perspective in education and greatly contributed to efficient management of schools globally. In reality ICT as sum total convergence between telecommunication, broadcasting multimedia and related technologies has promised a fundamental change in education within a short time and become a basic tool in modern school management. According to Krishnaveni and Meenakumari (2010), ICT is being used in schools to communicate, create, organize, disseminate, store, retrieve, and manage information which has made it possible for educational managers to be more efficient and accountable. This flow of information has allowed remote communities to become integrated into global networks making knowledge and culture accessible to anyone. On the same vein Oguta, Egessa and Musiega (2014) agreed that incorporation of ICT has given positive signs in most African schools in ensuring sound institutional management; a transparent and accountable governance; a 
thriving intellectual environment, a modicum of facilities; and an all effective leadership. In Kenya, the government encourages use of ICT as a tool to revolutionize management in schools to enhance more effective organizational structures and create a stronger links with the community and empower learners with skills necessary for independent learning. Through the Ministry of Education, Science and Technology (MOEST), the government of Kenya has provided a policy base for integration of ICT in education and training to enable learners and institutional managers to cope with management challenges arising from technological improvement and globalization.

The emergence of ICT has become a driving force for educational reforms, making it possible for school managers, staff, students and parents to exchange information and ideas ease and instantly. This has been witnessed in number of schools having websites and confirmed by Reddi (2011) who affirmed that to assess level of ICT use in education in Kenya, noted that schools are integrating ICT in management of finances, co-curricular activities and infrastructure and human resources management. Oguta, Egessa and Musiega (2014) asserted that ICT enhances day-to-day management of institutions and enables schools to improve in efficiency and cope with rapidly changing world in executing management tasks. In support of this contention Ngugi (2012) in an Investigation into the extent of use of ICT in education management in public secondary schools in Naivasha District, Kenya noted that cost-effective application of ICT related technology combined with flexibility in learning and administrative activities is essential in enhancing efficiency in secondary schools. As management tool ICT has made school management tasks less complex, which according to Mingaine (2013), includes coordination of teaching and learning process, along with educational programmes; financial, human resources and supporting resources; library and information science, and general administration. For coordination to achieve educational goals, Alexander (2012) grouped tasks as financial, administrative and instructional management. In financial management in schools ICT has been used in budgeting, accounting and auditing, which has streamlined financial management and minimized seepage. Again schools have used ICT in directing and controlling activities which includes staff and students' records management plus stores management and procurement implementation process. Instructional management in schools has used ICT in timetabling, examination management, academic records and teaching-learning process. The study sought to address administrative, financial and instructional management in private secondary schools in Nairobi County.

\subsection{ICT and Administrative Management in School}

Usage of ICT in administrative management involves harnessing technology for better planning, setting standards, effecting change and monitoring results of the core functions of secondary schools. According to O'Brien and Marakas (2011), ICT is used in maintenance of records, communication and documents management. A study carried by Oboegbulem and Ugwu (2013), in South Eastern States, Nigeria noted that influence of ICT on management systems have changed nature of administration in secondary school by allowing information to be transferred, stored, retrieved, and processed by almost all who work, study or interact within and outside the institutions. This according to Meryo and Boit (2012) has improved efficiency in day-to-day school operational activities especially in managing information about students, staff and resources. Based on this realization Makewa, Role and Nyamboga (2011) asserted that integration of ICT into secondary administrative processes enhance overall students' records by making it more accessible to many. However, Makhanu and Kamper (2012) further noted that ICT automation of admission process from enquiry by students, applying for admissions through electronic media, registration and enrolment using computers has improved management initiatives to adequately, handle both students and stakeholder related issues. On staff administration, Alexander (2012) asserted that ICT has enabled allocation of work, attendance, and leave management and performance appraisal, raising efficiency in task distribution, data collection and management. Oguta, Egessa and Musiega (2014), noted that ICT helps in staff management by processing of voluminous records in a quick, meticulous, and impeccable manner easening making data retrieval. In supporting of this position Mingaine (2013), indicated that ICT can help in providing a good communication system in providing timely information internal and external users acquisition and dissemination in all institution including schools.

\subsection{ICT and Financial Management in Schools}

Adoption of ICT is rapidly becoming an indispensable part of school life and an inevitable in financial management. In support of this position Ngugi (2012) noted that ICTs has become valuable for storing and analyzing data in school financial management which includes budgetary allocations, expenditures, students' fees payment and general accounting. Further according to Roberts and Sikes (2011) as an aspect of financial planning and control, budgeting process in schools requires the availability of multiple sources of information to cope which can best availed through incorporation of ICT in school management systems. Budgetary allocations as aspects of budgeting process in school management are intricate processes requiring reliable, timely, user-friendly information for supporting management decisions. While Makhanu and Kamper (2012) revealed that heads of secondary schools have utilized technology in 
planning and control in financial management, which greatly improved discipline in resource management. However use of ICT in private secondary schools in Nairobi remains weak. School managers are required to have basic information on supplies management and procurement to make decisions on budget monitoring and control, but Makewa, Role and Nyamboga (2011) noted that integration of ICT would make school financial information management systems much easier. Later, Wagithunu, Muthee and Thinguri (2014). indicated that ICT was critical in improving school financial information management systems through availing data to parents, students, government officials.

\subsection{ICT in School Instructional Management}

Instructional management aims at improving teaching and learning processes through a deliberate emphasis on ways and means of instilling excellence in quality of instruction. Today advances in ICT as noted by Roberts and Sikes (2011), require educators to present a more efficient and modern instructional management to equip students with knowledge and skills that stimulate creativity and spur growth. This is in line with assertion of Meryo and Boit (2012) that schools are designed to educate students, train for work and creativity cannot be complete without incorporating ICT in management systems. Interestingly instructional process is rapidly changing with integration of ICT as captured by Makhanu and Kamper (2012) who emphasized that blackboard that has been used in the schools for years is being replaced by smart board, books and notebooks with flash discs and memory card, overhead projectors with data projectors, and text-based assignments with presentations and slide show, which are more stimulating and imaginative. Furthermore, ICT is rapidly diminishing work load of keeping daily records of students, in analyzing students' attendance records, and in marking students' scripts and recording results. In acknowledging role of instructional management Makewa, Role and Nyamboga (2011) noted that ICT can now be used not only in formulation and implementation of schemes of work, but also in coordinating staff for effective teaching and learning processes. Instructional management involves guiding and influencing teachers and students to strive towards desirable teaching and learning behaviors to achieve educational goals and objectives, which ICT is ably filling the gap. To effectively guide the teachers and students Zuppo (2012) suggested that ICT can help schools to streamline instructional management to improve use of physical and human resources. With ICT scheduling of classes and other resources, handling internal and external examination activities can be achieved with increased efficiency in secondary schools.

\subsection{Emergence of Private Schools in Kenya}

Private schools in Kenya are owned by entrepreneurs, companies, churches, trusts and other players. Emergence could be traced to 1846 when missionaries established private schools with limited government control Kukali (2013). At independence the demand for more secondary schools resulted into the concept of Harambee or community based schools (Kipsoi, Chang'ach and Sang 2012). The communities were to build physical structure, hire teachers and support staff with limited assistance from the exchequer until 1988 when such institutions were integrated into public schools category on recommendation of Kamunge Commission Report of 1986. The emergence of Harambee schools offered a window for private entrepreneurs' entry into provision of secondary education in Kenya, which for a long time did not have sound educational management practices (Kiilu, 2012). While the public may have been slightly unfamiliar and uncomfortable with the concept of private schools at inception, indications were that such institution could provide equally superior education at secondary level (Makewa, Role \& Nyamboga 2011). This supports position, Meryo and Boit (2012) who had observed that however challenging, private sector's role in the provision of education had increased in efficiency as their administration became more responsive to the need of students, parents and community. Concurring with Meryo and Boit (2012), that private schools are increasingly becoming more efficient in managing instructional processes as well as administration and management, Oguta, Egessa and Musiega (2014) suggested that ICT could be more useful in making the instructions even more responsive to needs of students, parents and stakeholders.

\subsection{Statement of the Problem}

School managers construct virtual scenarios around different policy options to determine needs and analyze potential consequences of their actions and stimulate efficient management of resources for the good of stakeholders. Each scenario needs to be analyzed and evaluated systematically in terms of educational desirability, financial afford-ability, feasibility and sustainability over a sufficient period of time to show results. Most private schools in Kenya have existed for over 40 years (Kiilu, 2012) with management styles had previously reflecting limited use of ICT. However, reality for schools is existing management styles need modification to accommodate use of new ICTs following emergence of computers and Internet requiring school managers to use computers as a management tool (Makhanu and Kamper, 2012). The evolution of technology has given fresh impetus to use of ICT in management in schools. This 
calls for interrogating existing range of applications in raising management of resources at school level. However, how effective the use of ICT in management of private secondary schools in Nairobi County needed to be established. The study explored the extent adoption and accommodation of ICT use as a tool in financial, administrative and instructional management in private secondary schools in Nairobi County.

\subsection{Purpose of the Study}

The main objective of the study is to determine the effects of ICT in management of private secondary schools in Nairobi.

\subsection{Theoretical Approach}

The theory that could explain, describe, help to understand and predict the effect of ICT in school management is the scientific management theory. Frederic Taylor's scientific management theory advocated for definition of daily tasks and use of appropriate tools to perform them, (Krishnaveni \& Meenakumari, 2010). As tool ICT is used in information management to enable financial, administrative and instructional tasks in a school. ICT enables information about school policies and measures to easily be accessed for implementation school programmes. As tool ICT provides students and teachers with information on availability and conditions of textbooks, visual aids, science laboratory equipments for effective teaching and learning process in schools, (Adu \& Adu, 2013). The relevancy of scientific management theory to the study is that it explains the need of definition of daily tasks that could easily be achieved through use of ICT platform in managing students, staff, equipments, materials, facilities and finances. By integrating ICT, schools are capable of being efficient and effective management of financial tasks like accounts, payroll and budgeting; administrative records of stores, staff and students; and instructional processes like timetabling, examinations and academic progress reporting

\subsection{Conceptual Framework}

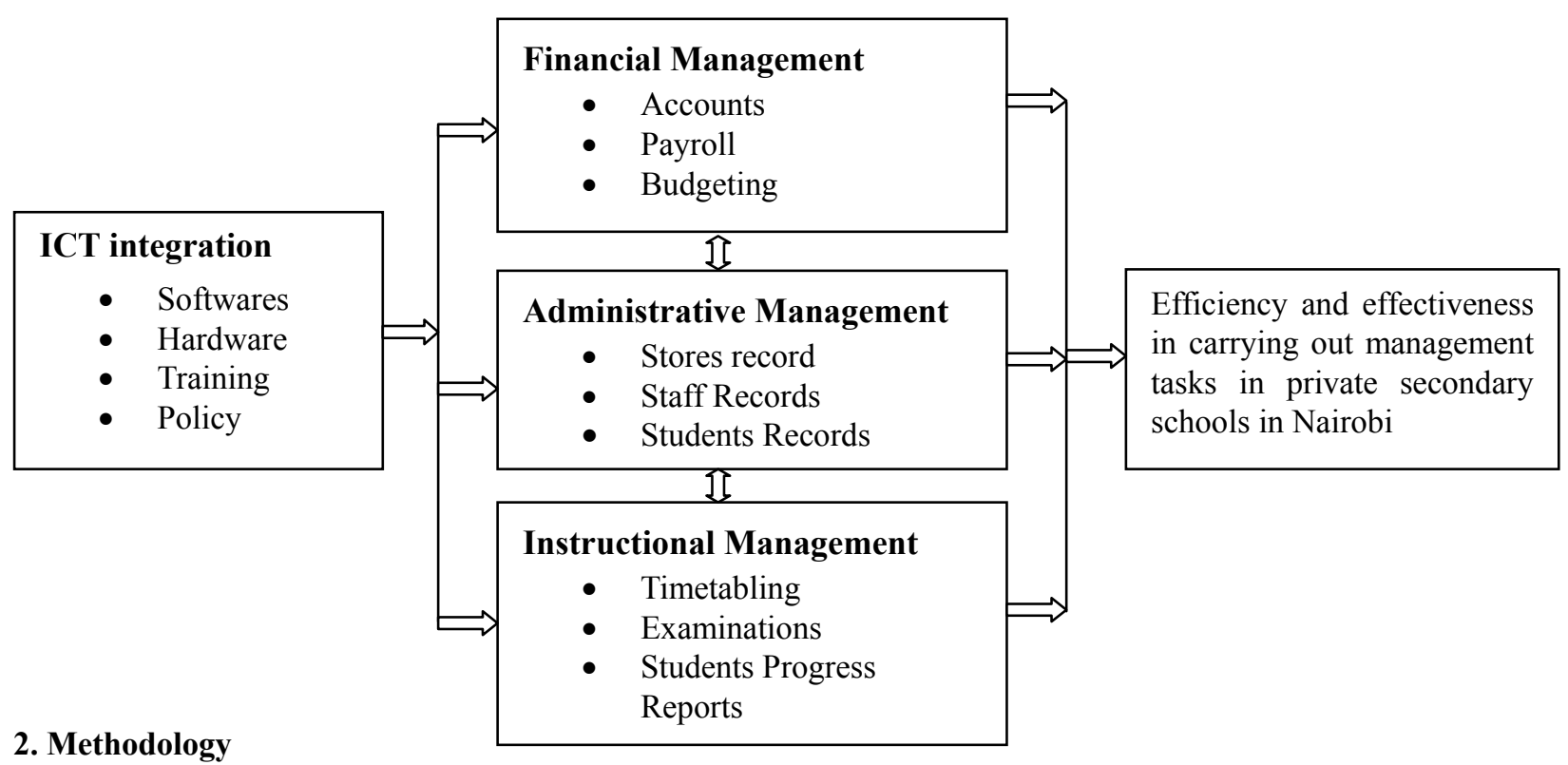

The survey design was to provide information on integration of ICT in management of private secondary schools in Nairobi using questionnaires and interviews to collect data. Survey design is particularly useful because the population was very large in dispersed areas large geographically (Roberts \& Sikes, 2011). The target population of the study was the 140 private schools in Nairobi and information was sourced from 40 principals, who were randomly sampled for the survey. The telephone numbers of schools with computers were serialized by assigning each with a number and using these serial numbers a sample population was obtained randomly through balloting. This study used three instruments; structured questionnaires, interviews and observations schedules to generate primary data. Data analysis involved the application of the two types of statistical technique namely descriptive statistics and presented using tables and figures.

\section{Finding and Discussion}

The information presented as findings was obtained from 32 questionnaires which were considered usable for 
meaningful analysis from sample 40 private secondary schools in Nairobi and returned within the specified period of 4 weeks. This yielded a response rate of $80 \%$, which was considered adequate for the purpose of this study.

Table 1. Characteristics of the Respondents and Schools

\begin{tabular}{|c|c|c|c|c|c|c|c|c|}
\hline \multicolumn{9}{|c|}{ Respondents } \\
\hline Age (Yrs) & Below 30 & $0 \%$ & $31-40$ & $47 \%$ & $41-50$ & $34 \%$ & Above 50 & $19 \%$ \\
\hline Experience & $1-5$ & $44 \%$ & $6-10$ & $34 \%$ & $11-15$ & $22 \%$ & Above 15 & $0 \%$ \\
\hline Training in IT & Certificate & $28 \%$ & Diploma & $34 \%$ & Degree & $4 \%$ & On job & $34 \%$ \\
\hline \multicolumn{9}{|c|}{ Schools } \\
\hline Enrollment & $0-150$ & $9 \%$ & $151-300$ & & $44 \%$ & Abov & 300 & $47 \%$ \\
\hline Curriculum & Foreign & $37 \%$ & Local (8-4-4) & & $32 \%$ & Both & & $31 \%$ \\
\hline Staff & $0-30$ & $32 \%$ & $31-60$ & & $44 \%$ & Abov & & $24 \%$ \\
\hline Type & Day & $13 \%$ & Boarding & & $22 \%$ & Both & & $65 \%$ \\
\hline Gender & Girls & $10 \%$ & Boys & & $14 \%$ & Mixe & & $76 \%$ \\
\hline Streams & Single & $13 \%$ & Double & & $56 \%$ & More & & $31 \%$ \\
\hline
\end{tabular}

In Kenya computers have been used in business and commerce for the last twenty five years while in education sector for about twenty years. People in management positions today aged above 50 years could have met ICT related technologies when in employment already and this could determine their willingness to accept it. This means older school principals could have found it difficult to embrace ICT, but had no choice to accept this convergence between telecommunication, broadcasting multimedia and related technologies that has promised a fundamental change in education (Krishnaveni \& Meenakumari, 2010). The study findings in table 1 has established that most principals 15 (47\%) were of ages $30-40,11(34 \%)$ fell between ages $40-50$ and $16(19 \%)$ were above 50 years of age. This is an indication that majority of private secondary schools in Nairobi are 50 years old or less and came into management position within the period computers came into use in the education sector. Secondly this position is further supported by the fact that majority have experience as principals less than fifteen years and came into leadership when ICT was already in day-to-day management of educational institutions. As indicated in table 1, 44\% of the principals have experience between one and five years; $34 \%$ six to ten years and remaining $22 \%$ having eleven to fifteen years. With none of the principals above 15 years it is an indication that schools in Nairobi County are part of rapidly changing world in executing management tasks through ICT as noted by Oguta, Egessa and Musiega (2014). ICT integration in schools has been made possible because most principals are trained on use of ICT with $28 \%$ having certificate level training, 34\% diploma, $4 \%$ degree and remaining $38 \%$ have acquired hands on computer skill working.

Student enrollment, curriculum offered, number of staff, gender of students, whether day or boarding and number of streams per class all determines complexity of administrative, financial and instructional tasks in terms of coordination. This complexity according to Krishnaveni and Meenakumari (2010) requires ICT to be used in schools to communicate, create, organize, disseminate, store, retrieve, and manage information. The study findings in table 1 indicates that most of private secondary schools in Nairobi County (47\%) have more than 300 students, $44 \%$ have between 150-300 enrollment and only 9\% with less than 150. This high enrollment necessitates ICT integration platform for school management information system, whichever curriculum offered for coordination of administrative, financial and instructional tasks. Table 1 show that $37 \%$ of private secondary schools in Nairobi County offer foreign curriculum, 32\% national 8-4-4 system and 31\% offer both. The existence of ICT based school management information system is also necessary in schools with more streams and as indicated in table 1 majority (56\%) of schools have double streams, $31 \%$ have more than two and $13 \%$ single streams.

\subsection{Effects of ICT in Management of Private Secondary Schools}

Educational institutions like secondary schools need to automate their core operations establishing integrated information systems targeted to address the finance, administrative and instructional records management functions. In this study the school principals were asked to tick which operations have been automated in financial, administrative and instructional management in their schools. 
Table 2. Level of ICT Integration in Management Task

\begin{tabular}{|c|c|c|c|c|c|c|c|c|}
\hline \multicolumn{3}{|c|}{ Financial Management } & \multicolumn{3}{|c|}{ Administrative Management } & \multicolumn{3}{|c|}{ Instructional Management } \\
\hline Tasks & $\mathbf{n}$ & $\%$ & Tasks & n & $\%$ & Tasks & $\mathbf{n}$ & $\%$ \\
\hline Accounts & 20 & 62.5 & Staff Records & 20 & 62.5 & Timetabling & 17 & 53.1 \\
\hline Payroll & 23 & 71.9 & Students Records & 18 & 56.25 & Examinations & 27 & 84.30 \\
\hline Budgeting & 17 & 53.1 & Stores Records & 22 & 68.75 & Academic Pro. reports & 25 & 78.13 \\
\hline
\end{tabular}

\subsubsection{Financial Management}

ICTs has become valuable for storing and analyzing data in school financial management which includes budgetary allocations, expenditures, students' fees payment and general accounting. In this study, automation of the budgeting, accounting and payroll were used to assess the effect of ICT in financial management. The study found out according to table 2 that $62.5 \%$ of schools have automated accounts, $71.9 \%$ payroll and $53.1 \%$ budgeting operations. The automation of accounts by $62.5 \%$ of schools is an indication that their accounting system can provide prudent control and proper accountability of all funds received by maintaining true and clear record which exhaustively identifies financial sources. Principals interviewed acknowledge that through ICT it has been easy to manage daily transactions through record keeping in journals, ledgers and cash book which has made financial analysis in terms of writing balance sheets, trial balances, trading accounts, and profit and loss account effectively carried out in schools. Secondly, automation of payroll by $71.9 \%$ of schools is an indication that through ICT they have laid down policies to guarantee timely and authorized transfer of money to individual staff account; work out deductions including taxes and other statutory obligations. Thirdly, study findings indicate that $53.1 \%$ of schools have automated their budgeting operations which include the allocation of funds to various school needs and usage. Through ICT principals noted that school needs are easily prioritized and managed by allocation funds according to the agreed projects depending on the available resources but must be within the management policy. This confirms what Glen (2007) noted that aspect of financial planning and control, budgeting process in schools requires the availability of multiple sources of information to cope which can best availed through incorporation of ICT in school management. This allows organizing and managing funds according to the population of students, infrastructure and staffing. There was general agreement that ICT has enabled schools to sets up systems for efficient control and effective accountability of finances, assets and other properties. Use of ICT can enabled all stakeholders in education participate in managing finances and in financial decision making especially in identifying the possible sources in budgeting as noted by a number of principals.

\subsubsection{Administrative Management}

Role of ICT in administrative tasks involves maintenance of records, communication and documents management. In this study automation of stores, students and staff records were used to determine the effects on ICT in administrative management of private secondary schools in Nairobi County. Findings in table 2 indicate that $68.75 \%$ of private schools have automated their stores, $56.25 \%$ students' records and $62.50 \%$ staff records. This is in line with Meryo and Boit (2012) assertion that usage of ICT in administrative management involves harnessing technology for better planning, setting standards, effecting change and monitoring results of the core functions. Secondly, in automating stores schools safeguard assets and ensure they are used solely for authorized purposes. Maintaining school stores records is a very tedious and time-consuming task. ICT manages all stores and sub-store items/consumables with various details required to be captured for these items. Principals from these schools noted that appropriate reports like issue of the items to staff and students is available on a mouse click in most schools and principals concurred that they can analyze the consumption more efficient. Other benefits noted are getting inventory balances, lots item information, minimum stock, outward and inward transaction details and many more. Records availed in some schools showed a variety of standard reports, such as lists of equipment stored at a given location, or the current values of specific categories of equipment, like printers, or other computer hardware. Interviews revealed that inspection and maintenance of premises and estates have been organized through the use of ICT. Staff records have information on human resource needs and interviews to highlight on the effect of ICT on human resource management found out that information stored related to payroll, financial forecasting of a school's staff costs and audits of teachers' skills and knowledge and planning of staff development. Principals agreed that appraisal and staff development could be organized, and records kept, analyzed in comparison with staff job descriptions; staff responsibilities. This supports Makewa, Role and Nyamboga (2011) assertion that ICT helps in staff management by processing of voluminous records in a quick, meticulous, and impeccable manner easening making data retrieval 


\subsubsection{Instructional Management}

Instructional management aims at providing a well-balanced education, starting from the selection of subjects, organizing the resources to the evaluation of the whole instructional programme. In this study, the effect of ICT on instructional management examined using automation of the school time table, examination administration and student academic progress reports. The study findings indicate that $53.10 \%$ of private secondary schools have automated time tabling. This has made it easy to monitor class attendance and maintenance through e-media, according to principals interviewed. In managing examinations $84.30 \%$ of schools in have automated exam activities. Among these activities according to principals interviewed are entries to examining bodies which are compiled and submitted on ICT platform. ICT is also useful in results analysis and printing in suitable formats for reporting to BOM, parents, subject departments within the school, class teachers, or individual pupils. Closely related to examination management ate students' progress reports which according to findings in figure 4 have been automated in $76.90 \%$ of private secondary schools in Nairobi County. In these schools according to interviews with principals, teachers are able to input the pupils' assessments, and comments for their pupils' school reports, using convenient input methods. A statement bank about pupils' progress is stored and teachers can edit and include in their reports for automatic generation to parents. The study findings are in line with Oguta, Egessa and Musiega (2014) suggestion that ICT can help schools to streamline instructional management to improve use of physical and human resources. This is in line with assertion of Kiilu (2012) that schools are designed to educate students, train for work and creativity cannot be complete without incorporating ICT in management systems.

\section{Conclusion}

With most of principals in secondary schools in Nairobi County aged below 50 years of age is an indication that most were willing to accept ICT. These principals have to accept convergence between telecommunication, broadcasting multimedia and related technologies that already bringing fundamental changes in education when they came into leadership. Secondly, with none of the principals above 15 years it is an indication that schools in Nairobi County are part of rapidly changing world in executing management tasks through ICT. Thirdly, most private secondary schools in Nairobi County have more than 300 students, which necessitates ICT integration platform for school management information system, whichever curriculum offered for coordination of administrative, financial and instructional tasks. And with many of these schools have double or three streams per class made existence of ICT based school management information system is necessary.

Integration of ICTs has become valuable for storing and analyzing data in private secondary schools in Nairobi County in financial management and specifically in managing budgeting process, expenditures, students' fees payment and general accounting. The automation of accounts in most of these schools is an indication that their accounting system can provide prudent control and proper accountability of all funds received by maintaining true and clear record which exhaustively identifies financial sources. Secondly, with automation of payroll in majority of schools is an indication that through ICT they have laid down policies to guarantee timely and authorized transfer of money to individual staff account; work out deductions including taxes and other statutory obligations. Thirdly, slightly more than half of schools have automated their budgeting operations which include the allocation of funds to various school needs and usage. Generally ICT has enabled schools to sets up systems for efficient control and effective accountability of finances, assets and other properties

Integration of ICT in administrative management has made it possible for private secondary schools in Nairobi County to be efficient and effective in managing records, communication and documents handling. Specifically, use of ICT involves harnessing technology for better planning, setting standards, effecting change and monitoring results of the core functions. Secondly, in automating stores schools safeguard assets and ensure they are used solely for authorized purposes. Schools leadership appreciates they can get inventory balances, lots item information, minimum stock, outward and inward transaction details and many more. These include standard reports, such as lists of equipment stored at a given location, or the current values of specific categories of equipment, like printers, or other computer hardware. ICT has enables management payroll, financial forecasting of a school's staff costs and audits of teachers' skills and knowledge and planning of staff development through processing of voluminous records in a quick, meticulous, and impeccable manner easening making data retrieval

The fact that most private schools in Nairobi County have integrated ICT in instructional management is pathway toward a well-balanced education, starting from the selection of subjects, organizing the resources to the evaluation of educational programmes. Automation of timetabling has made it easy to monitor class attendance and maintenance through e-media, according to principals interviewed, while in managing examinations it has enables entries to 
examining bodies, results analysis and reporting to BOM, parents, subject departments within the school, class teachers, or individual pupils. Automation has enabled input the pupils' assessments to create a statement bank about pupils' progress is stored and teachers can edit and include in their reports for automatic generation to parents. In conclusion the study findings show that ICT can help schools to streamline instructional management to improve use of physical and human resources.

\section{Recommendations}

The study recommends that ICT base school information management system would be very necessary for effectiveness and efficiency in carrying out financial, administrative and instructional tasks. Secondly, it recommends that the government of Kenya needs to make it a policy to reduce the cost of ICT infrastructure to be affordable through subsidy to enable as many schools to adopt ICT in their management. On the same argument every school should have a policy that gives the vision for how ICT will support the beliefs, values and goals of that school. The principal and the leadership team must ensure that the vision for ICT is shared with all staff, in order to move the school forward. This vision needs to be focused on what ICT will look like in the total environment of the school as an organization. Lastly it recommends further studies on role of ICT in planning, organizing and supervision in school management.

\section{References}

Adu, E.O., \& Adu, E.O. (2013). The Use and Management of ICT in Schools: Strategies for School Leaders. European Journal of Computer Science and Information Technology (EJCSIT), 1(2), 10-16.

Alexander A. (2012). The Impact of ICT on Educational Performance And Its Efficiency In Selected Eu And Oecd Countries: A Non-Parametric Analysis. University of Ljubtjana, Storenia. Retrieved from http://www.tojetnet/articles/viii3/11314.pdf

Kiilu R. (2012). An E-Learning Approach to Secondary School Education”: E- Readiness Implications in Kenya. Masinde Muliro University. $\quad$ Retrieved 2015 June, from http://www.iiste.org/Journals/index.php/JEB/article/viewfile/3707/3756

Kipsoi, E J., Chang'ach, J K., \& Sang H C. (2012). Challenges Facing Adoption of Information Communication Technology (ICT) In Educational Management in Schools in Kenya. Journal of Sociological Research, 3(1), 18-28. http://dx.doi.org/10.5296/jsr.v3i1.1882

Krishnaveni R., \& Meenakumari J. (2010). Usage of ICT for Information Administration in Higher education Institutions - A study. International Journal of Environmental Science and Development, 1(3), 282-286. http://dx.doi.org/10.7763/IJESD.2010.V1.55

Kukali A.N. (2013). Opportunities and Challenges for Use and Integration of ICT in management of Public Secondary Schools in Bungoma South District, Kenya. Maseno University Dept. of Education Management.

Makewa, L., Role, E., \& Nyamboga, R. (2011). Teacher evaluation of the Principal's leadership characteristics related to computer studies implementation in Rongo District, Kenya. International Journal of Education and Development using Information and Communication Technology (IJCDICT), 7(2), 5-14.

Makhanu E., \& Kamper G. (2012). The relationship between Principals Access to Information and Communication Technology (ICT) and School Performance in Kenya. University of South Africa, Pretoria 003. Retrieved June, 2015 from http://www.heraldjournals.org/hjegs/archive.htm

Makhanu E., \& Kamper G. (2012). The relationship between Principals "Access to Information and Communication Technology (ICT) and School Performance in Kenya. University of South Africa, Pretoria 003. Retrieved January, 2014 from http://www.heraldjournals.org/hjegs/archive.htm

Meryo D. K., \& Boit J.M. (2012). The Challenges of using Information Commuincation Technology in School Administration in Kenya. Moi University.

Mingaine L. (2013). Skill Challenges in Adoption and use of ICT in Public Secondary Schools, Kenya. Shanghai University, China. Retrieved in June 2015 from http://www.ijssnet.com/Jurnals/vol.3-No-13-July-2013/8.pdf

Ngugi P. (2012). An Investigation into the Extent of use of ICT in Education Management in Public Secondary Schools in Naivasha District, K.U.

O’Brien J. A., \& Marakas G.M. (2011). Management Information Systems (10th Edn.). McGraw Hill, New York, USA 
Oboegbulem, A., \& Ugwu, R N. (2013). The Place of ICT in the Administration of Secondary Schools in South Eastern States of Nigeria. US-China Education Review, 3(4), 231-238.

Oguta J O., Egessa R K. W., \& Musiega D. (2014). Effects of Information Communication and Technology (ICT) Application on Strategic Educational Quality Standards Management in Bungoma County, Kenya. International Journal of Business and Management Invention, 3(5), 11-17.

Reddi U.V. (2011). Role of ICTs in Education and Development: Potential, Pitfalls and Challenges. Retrieved from http:www.unesco.org/education/aladin/paldin/pdf/cpourseol/unit-13pdf

Roberts, R., \& Sikes, J. (2011). How IT is managing new demands: Mckinsey Global Survey Results. Mckinsey on Business Technology, 22(Spring), 24-33.

Wagithunu, M N., Muthee, J., \& Thinguri R. (2014). A Critical Analysis of School Principals’ Competence in Financial Management in Kenya: Accountability in Educational Planning and Management. Journal of Education and Practice, 5(25), 103-107. 